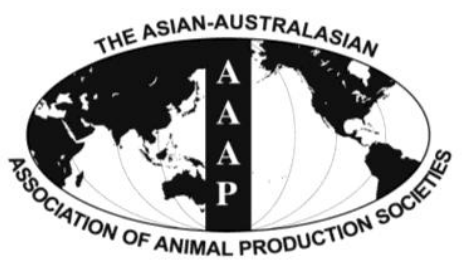

Asian-Aust. J. Anim. Sci.

Vol. 25, No. $10: 1439$ - 1444

October 2012

www.ajas.info

http://dx.doi.org/10.5713/ajas.2012.12215

\title{
Evaluation of Houttuynia cordata and Taraxacum officinale on Growth Performance, Nutrient Digestibility, Blood Characteristics, and Fecal Microbial Shedding in Diet for Weaning Pigs
}

\author{
L. Yan, Z. F. Zhang, J. C. Park ${ }^{1}$ and I. H. Kim* \\ Department of Animal Resource and Science, Dankook University, Cheonan, Choognam 330-714, Korea
}

\begin{abstract}
A total of 144 pigs ((Landrace $\times$ Yorkshire $) \times$ Duroc] with an average initial $\mathrm{BW}$ of $8.45 \pm 0.57 \mathrm{~kg}$ were used in a 5 -wk growth trial. Pigs were randomly allocated to 4 treatments with 9 replications per pen in a randomized complex block design. Dietary treatments included: i) CON (basal diet), ii) ANT (CON+tylosin $1 \mathrm{~g} / \mathrm{kg})$, iii) $\mathrm{H} 1(\mathrm{CON}+H$. cordata $1 \mathrm{~g} / \mathrm{kg})$ and iv) $\mathrm{T} 1(\mathrm{CON}+T$. officinale $1 \mathrm{~g} / \mathrm{kg}$ ). In this study, pigs fed the ANT and T1 treatment had a higher ( $<<0.05)$ average daily gain (ADG) and gain:feed (G:F) ratio than those fed CON and $\mathrm{H} 1$ treatment. Dietary ANT and T1 treatment led to a higher energy digestibility than the CON group. No difference $(\mathrm{p}>0.05)$ was observed on the growth performance and apparent total tract digestibility with H1 supplementation compared with the CON treatment. The inclusion of ANT treatment led to a higher $(\mathrm{p}<0.05)$ lymphocyte concentration compared with the CON treatment. Dietary supplementation of herbs did not affect $(\mathrm{p}>0.05)$ the blood characteristics (white blood cell (WBC), red blood cell (RBC), IgG, lymphocyte). No difference was observed on $(\mathrm{p}<0.05)$ fecal microbial shedding (E. coli and lactobacillus) between ANT and CON groups. Treatments H1 and T1 reduced the fecal E. coli concentration compared with the CON treatment, whereas the fecal lactobacillus concentration was not affected by the herb supplementation $(\mathrm{p}>0.05)$. In conclusion, the inclusion of T. officinale $(1 \mathrm{~g} / \mathrm{kg})$ increased growth performance, feed efficiency, energy digestibility similarly to the antibiotic treatment. Dietary supplementation of T. officinale and $H$. cordata $(1 \mathrm{~g} / \mathrm{kg})$ reduced the fecal E. coli concentration in weaning pigs. (Key Words: Houttuynia cordata, Taraxacum officinale, Growth, Digestibility, Fecal Microbes, Weaning Pigs)
\end{abstract}

\section{INTRODUCTION}

The ban of antibiotics utilization as feed additives in livestock resulted in a great interest on the antibiotics alternative in livestock industry. Among this, medicinal herbs was considered to be the a good one because of its stimulate effect on appetite and secretion of digestive enzymes (Wenk, 2003; Cho et al., 2006; Huang et al., 2010). Thus, a lot of medicinal herbs have been used as feed additives in pig production industry to stimulate the animal growth performance (Huang et al., 2010; Yan et al., 2010, Ao et al., 2011; Yan et al., 2011a, b; Yan et al., 2012 a; Yan and Kim, 2012).

Houttuynia cordata ( $H$. cordata) have been used in many traditional medicines because of their antimicrobial, antiviral and anti-inflammatory properties (Chang et al.,

\footnotetext{
* Corresponding Author: I. H. Kim. Tel: +82-41-550-3652, Fax: +82-41-565-2949, E-mail: inhokim@ dankook.ac.kr

${ }^{1}$ National Institute of Animal Science, RDA, Korea.

Submitted Apr. 23, 2012; Accepted Jul. 3, 2012; Revised Jul. 11, 2012
}

2001; Chiang et al., 2003). Kim et al. (2007) had previously suggested that $H$. cordata may be beneficial for the treatment of mast cell-mediated inflammation. Yan et al. (2011b) also suggested that the inclusion of $H$. cordata could increase the growth performance and nutrient digestibility in finishing pigs. Therefore, we hypothesized the inclusion of $H$. cordata extract powder could also benefit the weaning pig by improving their health status.

Taraxacum officinale (T. officinale) has also been used as medical herb for several human or animals for a long time because of its anti-inflammatory, anti-oxidative, antiallergic activity (Ho et al., 1998; Hagymasi et al., 2000). Our previous study (Yan et al., 2011b) had suggested that the inclusion of $T$. officinale could increase the growth performance and gut health in finishing pigs. Trojanova et al. (2004) also suggested that $T$. officinale could be used as a prebiotic in vitro.

The objective of our study was to evaluate the effect of $H$. cordata and T. officinale extract powder supplementation on growth performance, apparent total tract digestibility (ATTD), blood characteristics and fecal microbial shedding 
in weaning pigs.

\section{MATERIALS AND METHODS}

The experimental protocols were approved by the Animal Care and Use Committee of Dankook University (Cheonan, Choognam, Korea).

\section{Preparation of herb extracts mixture}

The dried plant leaves of $H$. cordata and T. officinale were chopped and pulverized to pass 100 mesh ( $2 \mathrm{~mm}$ ). An extract of the herb was prepared as described by Jang et al. (2008). Briefly, $100 \mathrm{~kg}$ of each powdered medicinal herb was extracted overnight with $200 \mathrm{~L}$ of $75 \%$ methanol by using a large-scale extractor at room temperature. The $75 \%$ methanol solution was filtered 2 to 3 times with cheesecloth, and the filtrate was concentrated by a rotary evaporator under vacuum, freeze-dried and crushed in the form of powder form.

\section{Experimental design, animals, and facilities}

A total of 144 pigs ((Landrace $\times$ Yorkshire $) \times$ Duroc) with an average initial BW of $8.45 \pm 0.57 \mathrm{~kg}$ were used in a 5 -wk growth trial. Pigs were randomly allocated to 4 treatments with 9 replications (Pens) each consisting of 4 pigs (two barrows and two gilts) in a randomized complex block design according to its BW and sex. Dietary treatments included: i) CON (basal diet), ii) ANT (CON+tylosin 1g/kg), iii) $\mathrm{H} 1(\mathrm{CON}+H$. cordata $1 \mathrm{~g} / \mathrm{kg})$ and iv) $\mathrm{T} 1(\mathrm{CON}+T$. officinale $1 \mathrm{~g} / \mathrm{kg}$ ). A 3-period feeding program was employed in the current experiment (Table 1), which consisted of phase 1 ( 0 to $1 \mathrm{wk}$ ), phase 2 (2 to $3 \mathrm{wks}$ ), phase 3 (4 to $5 \mathrm{wks}$ ). All diets used in the present study were formulated to meet or exceed the nutrient recommendations of the NRC (1998). The additive was supplemented in the diet by replacing the same amount of corn. The pigs were housed in an environmentally controlled nursery room. The stainless steel pens were $0.6 \times 2.0 \mathrm{~m}$ with a slatted plastic floor and a cage height of $0.5 \mathrm{~m}$. Each pen was provided with a stainless steel feeder and a nipple drinker that allowed for ad libitum access to feed and water throughout the experiment. Ventilation was provided by a mechanical system, and lighting was automatically regulated to provide $12 \mathrm{~h}$ of artificial light per day. The ambient temperature within the room was approximately $30^{\circ} \mathrm{C}$ and decreased by $1{ }^{\circ} \mathrm{C}$ each wk of the experiment.

\section{Sampling and measurements}

The individual pig BW and feed consumption (weekly) of each pen was monitored to calculate average daily gain (ADG), average daily feed intake (ADFI), and gain:feed ratio (G:F). Chromium oxide $\left(\mathrm{Cr}_{2} \mathrm{O}_{3}, 2 \mathrm{~g} / \mathrm{kg}\right.$ ) was added to the diets as an indigestible marker on d 29 to measure
Table 1. Compositions of basal diets (as-fed basis)

\begin{tabular}{|c|c|c|c|}
\hline Items & 0 to $1 \mathrm{wk}$ & 2 to 3 wks & 4 to $5 \mathrm{wks}$ \\
\hline \multicolumn{4}{|l|}{ Ingredient $(\mathrm{g} / \mathrm{kg})$} \\
\hline Extruded corn & 111.5 & 349.2 & 451.0 \\
\hline Extruded oat & 100.0 & - & - \\
\hline Bakery by products & - & 50.0 & 90.0 \\
\hline Soybean meal $(44 \% \mathrm{CP})$ & 80.0 & 200.0 & 296.5 \\
\hline Fermented soybean meal & 78.0 & 82.0 & - \\
\hline Fish meal & 50.0 & 40.0 & 25.0 \\
\hline Soy oil & 41.5 & 48.0 & 30.0 \\
\hline Lactose & 100.0 & 60.0 & - \\
\hline Whey & 170.0 & 107.0 & 68.5 \\
\hline Milk product & 130.0 & 20.0 & 20.0 \\
\hline Monocalcium phosphate & 12.5 & 10.0 & 6.0 \\
\hline Sugar & 40.0 & 20.0 & - \\
\hline Plasma powder & 65.0 & - & - \\
\hline L-Lys·HCl $(78 \%)$ & 1.2 & 2.5 & 1.6 \\
\hline DL-Met $(50 \%)$ & 2.6 & 1.5 & 1.4 \\
\hline L-Thr $(89 \%)$ & 7.7 & 0.8 & \\
\hline Choline chloride $(25 \%)$ & 2.0 & 1.0 & 1.0 \\
\hline Vitamin premix $^{1}$ & 1.0 & 1.0 & 1.0 \\
\hline Trace mineral premix ${ }^{2}$ & 2.0 & 2.0 & 2.0 \\
\hline Limestone & 2.0 & 2.0 & 3.0 \\
\hline Salt & 3.0 & 3.0 & 3.0 \\
\hline \multicolumn{4}{|c|}{ Calculated composition $(\mathrm{g} / \mathrm{kg})^{3}$} \\
\hline $\mathrm{ME}(\mathrm{MJ} / \mathrm{kg})$ & 14.8 & 14.8 & 14.6 \\
\hline $\mathrm{CP}$ & 220.0 & 210.0 & 205.0 \\
\hline Lys & 15.7 & 14.1 & 13.3 \\
\hline Met & 6.0 & 4.9 & 4.7 \\
\hline $\mathrm{Ca}$ & 8.0 & 7.8 & 7.5 \\
\hline Total P & 7.6 & 7.6 & 6.4 \\
\hline
\end{tabular}

${ }^{1}$ Provided per kilogram of complete diet: vitamin A, 11,025 IU; vitamin $\mathrm{D}_{3}, 1,103 \mathrm{IU}$; vitamin $\mathrm{E}, 44 \mathrm{IU}$; vitamin $\mathrm{K}, 4.4 \mathrm{mg}$; riboflavin, $8.3 \mathrm{mg}$; niacin, $50 \mathrm{mg}$; thiamine, $4 \mathrm{mg}$; d-pantothenic acid, $29 \mathrm{mg}$; choline, 166 $\mathrm{mg}$; and vitamin $\mathrm{B}_{12}, 33 \mu \mathrm{g}$.

${ }^{2}$ Provided per kilogram of complete diet: $\mathrm{Fe}\left(\mathrm{as} \mathrm{FeSO}_{4} \cdot 7 \mathrm{H}_{2} \mathrm{O}\right.$ ), $80 \mathrm{mg}$; $\mathrm{Cu}$ (as $\mathrm{CuSO}_{4} \cdot 5 \mathrm{H}_{2} \mathrm{O}$ ), $12 \mathrm{mg}$; $\mathrm{Zn}$ (as $\mathrm{ZnSO}_{4}$ ), $85 \mathrm{mg}$; $\mathrm{Mn}$ (as $\mathrm{MnO}_{2}$ ), $8 \mathrm{mg}$; I (as $\mathrm{KI}), 0.28 \mathrm{mg}$; and $\mathrm{Se}\left(\right.$ as $\left.\mathrm{Na}_{2} \mathrm{SeO}_{3} \cdot 5 \mathrm{H}_{2} \mathrm{O}\right), 0.15 \mathrm{mg}$.

${ }^{3}$ Calculated according to NRC (1998).

ATTD. Fresh fecal grab samples were obtained from at least two pigs (1 gilt and 1 barrow) in each pen on $d 35$ to determine the apparent digestibility of dry matter (DM), nitrogen $(\mathrm{N})$, and energy. All feed and feces samples were stored immediately at $-20^{\circ} \mathrm{C}$ until analysis. Fecal samples were dried at $70^{\circ} \mathrm{C}$ for $72 \mathrm{~h}$ and finely ground to pass through a 1-mm screen. The procedures utilized for the determination of DM and $\mathrm{N}$ digestibility were conducted in accordance with the methods established by the AOAC (2000). Chromium levels were determined via UV absorption spectrophotometry (UV-1201, Shimadzu, Kyoto, Japan) and the apparent total tract digestibility (ATTD) of $\mathrm{DM}$ and $\mathrm{N}$ were calculated using indirect methods described by Williams et al. (1962). The gross energy was 
Table 2. Effect of herb on growth performance in weaning pigs

\begin{tabular}{lccccc}
\hline Items $^{1}$ & CON & ANT & H1 & T1 & SE $^{2}$ \\
\hline ADG (g) & $495^{\mathrm{b}}$ & $654^{\mathrm{a}}$ & $501^{\mathrm{b}}$ & $594^{\mathrm{a}}$ & 35 \\
ADFI (g) & 716 & 733 & 721 & 704 & 11 \\
G:F & $0.691^{\mathrm{b}}$ & $0.892^{\mathrm{a}}$ & $0.694^{\mathrm{b}}$ & $0.843^{\mathrm{a}}$ & 0.021 \\
\hline
\end{tabular}

${ }^{1}$ CON = Basal diet; ANT = Basal diet+1 $\mathrm{g} / \mathrm{kg}$ tylosin; HE1 = Basal diet $+0.1 \%$ herb1. HE2 $=$ Basal diet $+0.1 \%$ herb2; HE3 = Basal diet $+0.1 \%$ herb3. $\mathrm{ADG}=$ Average daily gain $\mathrm{ADFI}=$ Average daily feed intake; $\mathrm{G}: \mathrm{F}=$ Gain:feed ratio

${ }^{2}$ Standard error.

${ }^{a, b}$ Means in the same row with different superscripts differ $(p<0.05)$.

determined by measuring the heat of combustion in the samples using a Parr 6100 oxygen bomb calorimeter (Parr instrument Co., Moline, IL, USA).

At the beginning of the experiment, two pigs (one gilt and one barrow) were randomly selected from each pen and bled via jugular venipuncture using a sterile needle into either a 5-ml or a $\mathrm{K}_{3}$ EDTA tube for subsequent analysis (Becton Dickinson Vacutainer Systems, Franklin Lakes, NJ, USA). The same pigs were then bled again at the end of the experiment, after which the serum was separated by centrifugation for $30 \mathrm{~min}$ at $2,000 \times \mathrm{g}$ and the aliquot was stored at $-4^{\circ} \mathrm{C}$ until it was analyzed for $\operatorname{IgG}$ using an automatic biochemistry blood analyzer (HITACHI 747 , Hitachi, Tokyo, Japan). The red blood cells (RBC), white blood cells (WBC), and lymphocyte counts of the whole blood samples were determined using an automatic blood analyzer (ADVIA 120, Bayer, Tarrytown, NY, USA).

At d 35, fecal samples were collected via massaging the rectum from 2 pigs randomly selected from each pen $(1$ gilt and 1 barrow) and pooled and placed on ice for transportation to the laboratory, where analysis was immediately carried out. The composite fecal sample (1 g) from each pen was diluted with $9 \mathrm{ml}$ of $1 \%$ peptone broth (Becton, Dickinson and Co.) and homogenized. Viable counts of bacteria in the fecal samples were then determined by plating serial 10 -fold dilutions (in $1 \%$ peptone solution) onto MacConkey agar plates (Difco Laboratories, Detroit, MI, USA) and lactobacilli medium III agar plates (Medium 638, DSMZ, Braunschweig, Germany) to isolate E. coli and Lactobacillus, respectively. The lactobacilli medium III agar plates were then incubated for $48 \mathrm{~h}$ at $39^{\circ} \mathrm{C}$ under anaerobic conditions. The MacConkey
Table 3. Effect of herb on nutrient digestibility in weaning pigs ${ }^{1}$

\begin{tabular}{llllll}
\hline Items (\%) & CON & ANT & H1 & T1 & SE $^{2}$ \\
\hline Dry matter & 79.94 & 80.47 & 79.70 & 81.40 & 2.97 \\
Nitrogen & 77.10 & 78.88 & 76.29 & 79.41 & 2.37 \\
Energy & $76.21^{\mathrm{b}}$ & $78.30^{\mathrm{a}}$ & $76.63^{\mathrm{b}}$ & $79.14^{\mathrm{a}}$ & 1.06 \\
\hline
\end{tabular}

${ }^{1} \mathrm{CON}=$ Basal diet; ANT = Basal diet+1 $\mathrm{g} / \mathrm{kg}$ tylosin; HE1 = Basal diet $+0.1 \%$ herb1. HE2 $=$ Basal diet $+0.1 \%$ herb2; HE3 = Basal diet $+0.1 \%$ herb3.

${ }^{2}$ Standard error.

agar plates were incubated for $24 \mathrm{~h}$ at $37^{\circ} \mathrm{C}$. Escherichia coli and Lactobacillus colonies were counted immediately after removal from the incubator.

\section{Statistical analyses}

Data were analyzed by ANOVA using the General Linear Models (GLM) procedure of SAS (SAS Institute, 1996), with the pen being defined as the experimental unit. Differences among treatments were separated by Duncan's multiple range test. The results were expressed as the least squares means and SE. Probability values less than 0.05 were considered significant.

\section{RESULTS}

\section{Growth performance and ATTD}

Pig fed the ANT and T1 treatment led to a higher ( $\mathrm{p}<$ 0.05) $\mathrm{ADG}$ and $\mathrm{G}: \mathrm{F}$ ratio than those fed $\mathrm{CON}$ and $\mathrm{H} 1$ treatment. The inclusion of $\mathrm{H} 1$ did not affect $(p>0.05)$ the ADG compared with the CON treatment. Dietary ANT and T1 treatment led to a higher energy digestibility than the CON group. No difference $(p>0.05)$ was observed on the apparent total tract digestibility with $\mathrm{H} 1$ supplementation compared with the CON treatment.

\section{Blood characteristics}

The inclusion of ANT treatment led to a higher ( $\mathrm{p}<$ 0.05) lymphocyte concentration compared with the CON treatment. Dietary supplementation of herb did not affect $(\mathrm{p}>0.05)$ the blood characteristics (WBC, RBC, IgG, lymphocyte) throughout the experiment.

\section{Fecal microbial shedding}

Pigs fed antibiotic supplemental diets did not affect

Table 4. Effect of herb on blood characteristics in weaning pigs ${ }^{1}$

\begin{tabular}{|c|c|c|c|c|c|}
\hline Items & $\mathrm{CON}$ & ANT & H1 & $\mathrm{T} 1$ & $\mathrm{SE}^{2}$ \\
\hline $\mathrm{WBC}\left(\times 10^{3} / \mu \mathrm{l}\right)$ & 14.70 & 15.37 & 13.77 & 13.99 & 2.93 \\
\hline $\mathrm{RBC}\left(\times 10^{6} / \mu \mathrm{l}\right)$ & 6.79 & 7.13 & 7.05 & 6.63 & 1.18 \\
\hline $\operatorname{IgG}(\mathrm{mg} / \mathrm{dl})$ & 1,153 & 1,264 & 1,131 & 1,193 & 97 \\
\hline Lymphocyte (\%) & $62.4^{\mathrm{b}}$ & $67.2^{\mathrm{a}}$ & $64.7^{\mathrm{ab}}$ & $66.2^{\mathrm{ab}}$ & 2.1 \\
\hline
\end{tabular}

${ }^{1} \mathrm{CON}=$ Basal diet; ANT = Basal diet+1 g/kg tylosin; HE1 = Basal diet $+0.1 \%$ herb1. HE2 = Basal diet $+0.1 \%$ herb2; HE3 = Basal diet $+0.1 \%$ herb3. WBC $=$ White blood cell; RBC, red blood cell.

${ }^{2}$ Standard error. 
Table 5. Effect of herb supplementation on fecal microbial shedding in weaning pigs ${ }^{1}$

\begin{tabular}{lllllc}
\hline Items & CON & ANT & H1 & T1 & SE $^{2}$ \\
\hline Escherichia coli & $7.83^{\mathrm{a}}$ & $7.74^{\mathrm{a}}$ & $7.38^{\mathrm{b}}$ & $7.27^{\mathrm{b}}$ & 0.14 \\
Lactobacillus & 8.59 & 8.61 & 8.57 & 8.63 & 0.18 \\
\hline${ }^{1}$ CON = Basal diet; & ANT $=$ Basal diet +1 & g/kg tylosin; HE1 $=$ Basal \\
diet $+0.1 \%$ herb1. HE2 = Basal diet $+0.1 \%$ & herb2; HE3 = Basal diet $+0.1 \%$ \\
herb3. \\
${ }^{2}$ Standard error.
\end{tabular}

$(\mathrm{p}<0.05)$ the fecal microbial shedding (E. coli and lactobacillus) at the end of this study (Table 5). The inclusion of $\mathrm{H} 1$ and $\mathrm{T} 1$ reduced the fecal $E$. coli concentration compared with the CON treatment, whereas the fecal lactobacillus concentration was not affected with the herb supplementation ( $\mathrm{p}>0.05)$.

\section{DISCUSSION}

\section{Growth performance and nutrient digestibility}

It is well accepted that antibiotic supplementation could greatly improve the growth performance of swine because of its antimicrobial effect and health promoting effect (Yan et al., 2011a). Wang et al. (2011) had previously suggested that the inclusion of antibiotic could improve the growth performance of growing pig. Our previous study (Yan et al., 2011c) also suggested that pig fed antibiotic supplemental diet could improve the growth performance and digestibility compared with those fed normal diet. Similarly in this study, the inclusion of antibiotics led to a higher ADG and G:F, which again confirmed the antibiotic effect on the weaning pigs.

In terms of the herbal feed additives, the inclusion of $\mathrm{T} 1$ treatment led to higher $\mathrm{ADG}$ than the $\mathrm{CON}$ treatment, which is in agreement with our previous study (Yan et al., 2011b), who suggested that dietary T1 treatment increased the ADG of finishing pigs. However, it should be noted that the ADFI was also increased with $\mathrm{T} 1$ supplementation in that study, which was not the case in this study. But interestingly, dietary $\mathrm{T} 1$ treatment increased the G:F ratio compared with CON treatment, indicating the reason for the improved ADG was not its beneficial effect on feed intake, but its improved nutrient utilization. Indeed, supplementation of $T$. officinale increased the energy utilization compared with the CON group, which confirm its effect on the energy utilization. Similarly, our previous result (Yan et al., 2010) also suggested that dietary plant essential oil increased the feed efficiency and nutrient digestibility in grower and finisher pigs. But in contrast, pig fed the $\mathrm{H} 1$ treatment did not affect the growth performance throughout the experiment, which is inconsistent with our previous study in finishing pig (Yan et al., 2011a), who suggested that the inclusion of $H$. cordata increased the
ADG and ADFI compared with the CON group. Since the pigs age used in those two studies were different; therefore, we hypothesized that the reason for the difference is likely to be the different animal and different age used in each study. However, further study is still necessary to investigate its exactly mechanism before applying this herb in swine industry.

\section{Blood characteristics}

In the present study, dietary antibiotic led to a higher lymphocyte concentration than the control treatment, which is in agreement with our previous study (Yan et al., 2011b), who suggested that the inclusion of antibiotic increased the lymphocyte concentration. It is well suggested that gastrointestinal tract together with its associated lymphoid system are the largest immunologically competent organ in the body (Michael, 1988). Therefore, we hypothesized the beneficial effect of antibiotic on the lymphocyte concentration may be attributed to the improved gut health caused by the antibiotic supplementation.

However, supplementation of $\mathrm{H} 1$ and $\mathrm{T} 1$ did not significantly affect the lymphocyte concentration, although there were a numerically increase. In agreement with this study, our previous study (Yan et al., 2011b) also suggested that the supplementation of $H$. cordata or $T$. officinale did not affect the lymphocytes concentration in growing pigs. But in contrast, Kong et al. (2007) had suggested that the inclusion of herbal ultra-fine powder enhanced the production of cytokines and lymphocyte proliferating activity in piglets. Yan et al. (2011a) also suggested that the inclusion of herb extract mixture increased the lymphocyte concentration in finishing pig. The reason for the difference is likely to be the different herb used in different studies. Therefore, this study together with our previous study (Yan et al., 2011b) confirmed that the inclusion of $H$. cordata or T. officinale will not affect the lymphocyte concentration in pigs.

\section{Fecal microbial shedding}

Previously, it is well suggested that herbs and spices could significantly affect the pathogens in vitro because of its antimicrobial actions ( $\mathrm{Si}$ et al., 2006). Windisch et al. (2008) had suggested that herbs and spices could influence pathogenic microorganisms' growth in the gastrointestinal ecosystem, and subsequently increase the resistance of the animal exposed to different stress situations. Other authors (Insoft et al., 2005; Michael and Marteau, 2007) also suggested that the maturation and optimal development of immune system are highly related to the development and composition of the indigenous microflora and vice versa. Therefore, the fecal microbial shedding was investigated in this study. Our results indicated that supplementation of $\mathrm{H} 1$ 
and $\mathrm{T} 1$ significantly reduced the $E$. coli concentration compared with the control treatment, which is in agreement with Jugl-Chizzola et al. (2005), who suggested thyme supplementation could decrease the fecal E. coli concentration in piglets. However, some studies have failed to find effect of phytogenic compound on the fecal shedding of specific pathogens (Namkung et al., 2004; Hagmüller et al., 2006), and concluded that the reason for the discrepancies may be due to the differences in the quality of herbal materials, selection of particular herbs and forms of their administration (Windisch et al., 2008).

\section{CONCLUSION}

In conclusion, the inclusion of $T$. officinale supplementation $(1 \mathrm{~g} / \mathrm{kg})$ increased growth performance, feed efficiency, energy digestibility similarly to the antibiotic treatment. Dietary supplementation of $T$. officinale and $H$. cordata $(1 \mathrm{~g} / \mathrm{kg})$ reduced the fecal $E$. coli concentration in weaning pig due to its antimicrobial effect.

\section{ACKNOWLEDGEMENT}

This work was supported by the grant from the institute of Bio-Science and Technology (IBST) AT Dankook University in 2012.

\section{REFERENCES}

AOAC. 2000. Official methods of analysis. 17th ed. Assoc. Off. Analysis Chemistry, Gaithersburg, MD.

Ao, X., L. Yan, T. X. Zhou, J. P. Wang, Q. W. Meng, H. J. Kim, J. H. Cho and I. H. Kim. 2011. Effects of Saururus chinensis extract supplementation on growth performance, meat quality and slurry noxious gas emission in finishing pigs. Livest. Sci. 138:187-192.

Chang, J. S., L. C. Chiang, C. C. Chen, L. T. Liu, K. C. Wang and C. C. Lin. 2001. Antileukemic activity of Bidens pilosa L. var. minor (Blume) Sherff and Houttuynia cordata Thunb. Am. J. Chin. Med. 29:303-312.

Chiang, L. C., J. S. Chang, C. C. Chen, L. T. Ng and C. C. Lin. 2003. Anti-Herpes simplex virus activity of Bidens pilosa and Houttuynia cordata. Am. J. Chin. Med. 31:355-362.

Cho, J. H., Y. J. Chen, B. J. Min, H. J. Kim, O. S. Kwon, K. S. Shon, I. H. Kim, S. J. Kim and A. Asamer. 2006. Effects of essential oils supplementation on growth performance, IgG concentration and fecal noxious gas concentration of weaned pigs. Asian-Aust. J. Anim. Sci. 19:80-85.

Hagmüller, W., M. Jugl-Chizzola, K. Zitterl-Eglseer, C. Gabler, J. Spergser, R. Chizzola and C. Franz. 2006. The use of Thymi Herba as feed additive $(0.1 \%, 0.5 \%, 1.0 \%)$ in weanling piglets with assessment of the shedding of haemolysing E. coli and the detection of thymol in the blood plasma. Berl. Munch. Tierarztl. Wochenschr. 119:50-54.

Hagymási, K., A. Blazovics, J. Feher, A. Lugasi, S. T. Kristo and T.
Kery. 2000. The in vitro effect of dandelion antioxidants on microsomal lipid peroxidation. Phytother. Res. 14:43-44.

Huang, Y., J. S. Yoo, H. J. Kim, Y. Wang, Y. J. Chen, J. H. Cho and I. H. Kim. 2010. Effects of dietary supplementation with blended essential oils on growth performance, nutrient digestibility, blood profiles and fecal characteristics in weanling pigs. Asian-Aust. J. Anim. Sci. 23:607-613.

Ho, C., E. J. Choi, G. S. Yoo, K. M. Kim and S. Y. Ryu. 1998. Desacetylmatricarin, an anti-allergic component from Taraxacum platycarpum. Planta Medica 64:577-578.

Jang, A., X. D. Liu, M. H. Shin, B. D. Lee, S. K. Lee, J. H. Lee and C. Jo. 2008. Antioxidative potential of raw breast meat from broiler chicks fed a dietary medicinal herb extract mix. Poult. Sci. 87:2382-2389.

Jugl-Chizzola, M., J. Spergser, F. Schilcher, J. Novak, A. Bucher, C. Gabler, W. Hagmuller and K. Zitterl-Eglseer. 2005. Effects of Thymus vulgaris L. as feed additive in piglets and against haemolytic E. coli in vitro. Berl. Munch. Tierarztl. Wochenschr. 118:495-501.

Insoft, R. M., I. R. Sanderson and W. A. Walker. 2005. Development of immune function in the intestine and its role in neonatal diseases. Pediatr. Clin. North Am. 43:551-571.

Kim, I. S., J. H. Kim, J. S. Kim, C. Y. Yun, D. H. Kim and J. S. Lee. 2007. The inhibitory effect of Houttuynia cordata extract on stem cell factor-induced HMC-1 cell migration. J. Ethnopharmacol. 112:90-95.

Kong, X. F., Y. L. Yin, H. J. Liu, F. G. Yin, T. J. Li, R. L. Huang, P. Kang, F. F. Xing, G. Y. Wu, M. Z. Fan, C. B. Yang and Q. H. He. 2007. Effects of Chinese herbal ultra-fine powder as dietary additive on growth performance, serum metabolites and intestinal health in early-weaned piglets. Livest. Sci. 108:272-275.

Michael, L. G. G. 1988. Gastrointestinal absorption of intact proteins. Annu. Rev. Nutr. 8:329-350.

Michael de, V. and P. R. Marteau. 2007. Probiotics and prebiotics: effects on diarrhea. J. Nutr. 137:803S-811S.

Namkung, H., M. Li, J. Gong, H. Yu, M. Cottrill and C. F. M. Lange. 2004. Impact of feeding blends of organic acids and herbal extracts on growth performance, gut microbiota and digestive function in newly weaned pigs. Can. J. Anim. Sci. 84:697-704.

NRC. 1998. Nutrient requirement of swine. $10^{\text {th }}$ ed. Natl. Acad. Press, Washington, DC, USA.

Si, W., J. Gong, R. Tsao, T. Zhou, H. Yu, C. Poppe, R. Johnson and Z. Du. 2006. Antimicrobial activity of essential oils and structurally related synthetic food additives towards selected pathogenic and beneficial gut bacteria. J. Appl. Microbiol. 100: 296-305.

Trojanova, I., V. Rada, L. Kokoska and E. Vlkova. 2004. The bifidogenic effect of Taraxacum officinale root. Fitoterapia 75: 760-763.

Wang, J. P., J. H. Jung and I. H. Kim. 2011. Effect of dietary supplementation with delta-aminolevulinic acid on growth performance, hematological status and immune response of weaning pigs. Livest. Sci. 140:131-135.

Wenk, C. 2003. Herbs and botanicals as feed additives in monogastric animals. Asian-Aust. J. Anim. Sci. 16:282-289.

Williams, C. H., D. J. David and O. Iismaa. 1962. The 
determination of chromic oxide in faeces samples by atomic absorption spectrophotometry. J. Agric. Sci. 59:381-385.

Windisch, W., K. Schedle, C. Plitzner and A. Kroismayr. 2008. Use of phytogenic products as feed additives for swine and poultry. J. Anim. Sci. 86:E140-E148.

Yan, L., J. P. Wang, H. J. Kim, Q. W. Meng, X. Ao, S. M. Hong and I. H. Kim. 2010. Influence of essential oil supplementation and diets with different nutrient densities on growth performance, nutrient digestibility, blood characteristics, meat quality and fecal noxious gas content in grower-finisher pigs. Livest. Sci. 128:115-122.

Yan, L., Q. W. Meng and I. H. Kim. 2011a. The effect of an herb extract mixture on growth performance, nutrient digestibility, blood characteristics and fecal noxious gas content in growing pigs. Livest. Sci. 141:143-147.
Yan, L., Q. W. Meng and I. H. Kim. 2011b. The effects of dietary Houttuynia cordata and Taraxacum officinale extract powder on growth performance, nutrient digestibility, blood characteristics and meat quality in finishing pigs. Livest. Sci. 141:188-193.

Yan, L., J. H. Lee, Q. W. Meng and I. H. Kim. 2011c. Evaluation of the Anion supplementation on growth performance, nutrient digestibility, blood characteristics and fecal noxious gas content in weaning pigs. J. Appl. Anim. Res. 39:36-40.

Yan, L., Q. W. Meng and I. H. Kim. 2012. Effect of an herb extract mixture on growth performance, nutrient digestibility, blood characteristic, and fecal microbial shedding in weaning pigs. Livest. Sci. 145:189-195.

Yan, L., and I. H. Kim. 2012. Effect of eugenol and cinnamaldehyde on the growth performance, nutrient digestibility, blood characteristics, fecal microbial shedding and fecal noxious gas content in growing pigs. 25: 1178-1183. 